\title{
Two Grandfathers
}

\section{Mary Kennan Herbert}

Au cour de l'Amérique, les liens du sang sont nécessaires à l'histoire de la généalogie et de soi-même. C'est aussi le cas, bien sûr, pour les histoires familiales des autres nations, peuples et traditions. Les images des grands-parents marquent pour le meilleur ou encore le pire chaque nouvelle génération. Enfant, à Saint Louis, au Missouri, je savais intuitivement, à l'âge de 7 ans, le statut conféré aux visiteurs plus âgés de la famille et leur pouvoir potentiel. Mon grand-père était déjà mythique bien avant que je ne le rencontre. Quand je le vis, en dépit des récits de ma mère, il n'était pour moi qu'un vieil homme nous rendant visite. Seul le lien de sang fut crucial pour le rendre à nouveau précieux à mes yeux. A sept ans, je lui demandais, en quelque sorte, de me prouver ce qu'il pouvait être pour moi. C'était un test que je lui faisais passer. Mon autre grand-père, déjà mort, n'était pas l'objet de tels soupçons. Le sang parlait tout seul.

Number two was a farmer who followed the rules: he wore a straw boater from late May to Labor Day.

Thus, hat and cigar in hand, he stood in the living room, waiting for my mother, smoking silently until this poem

announced his arrival. I was puzzled that he walked in without knocking. He did not knock, he had rights then,

as an elder, acreage or no. I followed my nose to find him. I was clever, free of property or fields, age seven.

Late afternoon sun streamed through the front door, illuminations captured in cigar plumes. Rich or poor,

this man's thatch of silver hair was carefully combed. Still handsome, he studied his watch, puffing alone, 
until he noticed me, a brook in the meadow needing his attention. He advised, "I'll just wait here, DeeDee,

until your mother comes home." So he waited. Fated to live five years, longer than the other one already dead.

That summer afternoon I stood in awe of his snowy hair, his knuckles on a cane, smoke signals wafting in the air.

The other grandfather, number one, didn't enjoy stogies anymore. Number one lay six feet under the grass.

Number one was a common laborer. How could he be common, I wondered. These labels were new to me.

Dead grandparents are common. I looked at the old man's weathered face. He had ruled fields of corn

in another place. Grandfather number two owned a skull similar to the one underground. Same number of bones.

Seeds of flowers soon began to sprout or rot, or even if not, life and death are a word game, a straw hat, smoke. 